Colebrook, L. \& Purdie, A.W. (1937) Treatment of 106 cases of puerperal fever by sulpanilamide (streptocide). Lancet, ii, 1237.

Commission on Acute Respiratory Diseases (1947) Role of Lancefield Groups of beta-haemolytic streptococci in respiratory infections. New Engl. J. Med. 236, 157.

Eickhoff, T.C. Klein, J.O., Daly, A.K., Ingall, D. \& Firland, M. (1964) Neonatal sepsis and other infections due to Group B beta-haemolytic streptococci. New Engl. J. Med. 271, 1221.

FrY, R.M. (1938) Fatal infections by haemolytic streptococcus Group B. Lancet, i, 199.

Hood, M., JANNeY, A. \& Dameron, G. (1961) Beta haemolytic streptococcus Group B associated with problems of perinatal period. Amer. J. Obstet. Gynaec. 82, 809.

Keitel, H.G. Hanariman, J., Ting., Prince, L.N. \& RANDALl, E. (1962) Meningitis in the new born infant. J. Pediat. 61, 39.

KeXel, G. \& KHonhohn, S. (1965) Streptococcus alagactiae als Erreger von Säuglingsmeningitiden. Dtsch. med. Wschr. 90, 258.

LANCEFIELD, R.C. (1933) Serological differentiation of human and other groups of haemolytic streptococci. J. exp. Med. $57,571$.

LANCEFIELD, R.C. (1934) Serological differentiation of specific types of bovine haemolytic streptococci Group B. J. exp. Med. 59, 441.
MANNIK, M., Baringer, J.R. \& Stokes, J. (1962) Infections due to Group B beta-haemolytic streptococci: report of 3 cases and review of literature. New Engl.J. Med. 266, 910.

DE MOOR, C.E. (1960) Sepsis durch Sc. agalactiae. Versl. Volksgezondh. Nr. 1

OBiger, G. (1964) Zur Pathogenität von Gruppe B-Streptokokken (Sc. agalactiae) für Mensch und Rind und über experimentelle Infektionen mit humanen AgalactiaeStämmen an der bovinen Milchdrüse. Z. Hyg. Infekt, 149, 446.

RANTZ, L.A. \& KIRBY, W.M.M. (1942) Streptococcal meningitis : 4 cases treated with sulphonamides in which etiological agent was unusual streptococcus. Amer. intern. Med. 16, 716.

SeelemanN, M. (1941) Streptokokken bei Tieren und Ihre Ubertragbarkeit auf den Menschen. Ergebnisse der Hygiene Bakteriologie Immunitatsforschung und Experimentellen Therapie, Vol. 24, pp. 463-549, Verlag von Julius, Springer, Berlin.

Sicherman, M.J. (1965) Septicemia due to group B streptococcus: Report of two siblings presenting with lesions resembling erythema nodosum. Pediatrics, 36, 6, 937.

WheEler, S.M. \& Foley, G.E. (1943) A note on non group A streptococci associated with human infection. J. Bact. 46, 391.

Winterbauer, R.H., Fortune, R. \& Eickoff, T.C. (1966) Unusual occurrence of Neonatal Meningitis due to group B beta-haemolytic streptococci. Pediatrics, 38, 4, 661 .

\title{
Gas gangrene after amputation for peripheral vascular disease
}

\author{
I. G. SCHRAIBMAN* \\ F.R.C.S.(Edin.), F.R.C.S. \\ Late Casualty Surgeon, Alfred Hospital, Melbourne
}

ANAEROBIC myositis after amputation through poorly vascularized tissues is usually rapidly fatal. Although this complication has been well recorded (Ham, MacKenzie \& Loewenthal, 1964 ; Karasewick et al., 1964) it appears that it is still a cause of death which may be avoidable. Two such patients are reported who died in this hospital within the space of 3 months from gas gangrene. A therapeutic and prophylactic regime is outlined.

\section{Case reports}

\section{Case 1}

A.E.G., male, aged 84, an ex Salvation Army Officer was admitted on 9 June 1965 with established gangrene of part of the left foot which had been present for 8 weeks. This was associated with some pain, the intensity of which was difficult to gauge.

$\mathrm{He}$ was a diabetic of 10 years standing and at

\footnotetext{
*Present address: Hyperbaric Oxygen Unit, Department of Surgery, Western Infirmary, Glasgow, W.1.
}

the time of admission he was controlled on a 15 portion diet and 16 units of Lente insulin daily.

In 1958 he had been admitted with septic arthritis of the left first metatarso-phalangeal joint and again later that year with two indolent ulcers on the left foot, which lesions had gradually healed.

He was a rather frail old man. The blood pressure was $160 / 80 \mathrm{mmHg}$ and the pulse was irregular due to extrasystoles. The left foot was relatively warm, but there were no pedal pulses palpable. There was dry gangrene of the lateral border of the foot, all four lateral toes and the lateral half of the hallux.

The right foot was cold and pulseless, but there was no gangrene.

Operation: On 11 June a mid-thigh amputation was carried out under a general anaesthetic. This was the traditional operation at the site of election $25 \mathrm{~cm}$ distal to the greater trochanter. Generous skin flaps were allowed. The muscles were sutured over the end of the bone stump; 
at the time it was noted that the femoral artery was completely occluded and there was very little bleeding from the cut muscle. A double corrugated drain was sewn in and pressure bandages applied. No antibiotics were given.

Progress: The following morning, $18 \mathrm{hr}$ after operation, his pulse rate was $110 / \mathrm{min}$ and more irregular than it had previously been. His temperature commenced to rise. His bladder was palpable and as he could not pass urine an indwelling catheter was inserted and $750 \mathrm{ml}$ of urine drained.

His diabetic state worsened rapidly-the urine now contained sugar in quantity, and ketones. It was observed that there was oozing from the amputation site which stained the bandages, but this was not such as to cause concern.

On the following day ( $42 \mathrm{hr}$ after operation) his temperature was $39^{\circ} \mathrm{C}$ and pulse $110 / \mathrm{min}$. The ooze was now foul-smelling and when the dressings were removed there was gross subcutaneous gas formation in the remainder of the limb. A swab was taken which showed Clostridium welchii on smear and culture.

The patient was now treated with intramuscular procaine penicillin (1 mega-unit 3 hourly) and gas gangrene polyvalent antiserum $(30,000$ units intravenously after a subcutaneous test dose); two pints of blood were transfused.

In spite of these measures, he died $60 \mathrm{hr}$ after operation.

\section{Case 2}

R.S., male, aged 75, a casual gardener was admitted on 1 September 1965 with gangrene of the toes of the right foot, which was not painful. In 1963 the patient had undergone bilateral lumbar sympathectomy for rest pain in both feet, more severe on the right. He had made an uninterrupted recovery then from this procedure and his rest pain had been abolished.

He was a healthy-looking man. His pulse rate was $64 / \mathrm{min}$ with numerous extrasystoles and his blood pressure was $150 / 70 \mathrm{mmHg}$. There was no cardiac decompensation.

The right foot felt cold distal to the ankle and there was dry gangrene of the second, third and fourth toes. Both femoral pulses were palpable, but no pulse distal to these was felt in either leg.

Treatment: On 3 September a standard right mid-thigh amputation was performed. The muscles were apposed over the bone end and the wound was drained. No antibiotics were administered.

Progress: About $18 \mathrm{hr}$ after the operation, there was a sustained rise in pulse rate which occasioned no comment.
The following morning ( $24 \mathrm{hr}$ after operation), the temperature was $37.4^{\circ} \mathrm{C}$ and the pulse rate 3 was $110 / \mathrm{min}$. The patient looked unwell and $\underset{\complement}{\stackrel{\Phi}{\varrho}}$ there was a tinge of jaundice to the conjunctivae. $c$. There was a brownish maladorous discharge $\vec{F}$ from the operation site and the stump was $\stackrel{\text { ? }}{9}$ swollen, discoloured and crepitant. A swab was? taken which revealed Clostridium welchii on $\frac{\bar{D}}{\bar{D}}$ direct smear and culture.

The sutures were removed, thus allowing the $\stackrel{\overparen{D}}{\Omega}$ wound to be opened widely. Oxygen was administered by face-mask. Crystalline penicillin was $\vec{P}$ given in large doses and a blood transfusion was commenced. The patient was transferred to the $\vec{\omega}$ Oxygen Unit at Peter McCallum Clinic for treatment with hyperbaric oxygen by Dr H. A. S. Van den Brenk.

He was placed in the tank and the pressure raised to $3 \mathrm{~atm}$ absolute $\left(30 \mathrm{lb} /\right.$ in $^{2}$ gauge pres- $c 7$ sure). He was rather restless while under pres- $\vec{\omega}$ sure, and after $1 \frac{1}{2} \mathrm{hr}$ in the tank he died. of

A necropsy was performed which revealed no other cause of death apart from the gas gangrene.

\section{Discussion}

The gas-forming anaerobic organisms are ubiquitous. They are harmless commensals is man's gastro-intestinal tract and may be found anywhere on the skin, more especially in the perineum.

They produce disease in circumstances which favour exsporulation and rapid spread, viz. relative anoxia and the presence of dead tissues. Clinical infection thus depends on the soil rather than the seed.

Gas gangrene after amputation for peripheral vascular disease is a well-recognized entity (Gye, Rountree \& Lowenthal, 1961) as the 'soil' is particularly propitious for the organism. It is, therefore, incumbent upon a surgeon who performs this operation in the presence of vascular occlusion to be aware of the possibility and take measures to prevent its occurrence. The following measures are suggested:

(1) As most Clostridia are sensitive to penicillin (Nagler, 1945), prophylactic crystalline penicillin should be given by injection in a dose of at least 10 mega-units $/ 24 \mathrm{hr}$. This should commence $24 \mathrm{hr}$ prior to surgery as the drug may have to diffuse slowly through avascular areas at the site of $\underset{\omega}{N}$ amputation.

(2) Sutures to oppose the muscle ends over the bone should be avoided if the muscle is $\frac{D}{\Phi}$ bloodless and even if bleeding is satisfactory, they $\stackrel{?}{?}$ should be slack.

(3) These wounds should always be drained, even if haemostasis is easily attained. A tube 
drain with side holes may be more effective in allowing access for air than the usual corrugated drain.

(4) The wound should be inspected daily.

(5) An hourly pulse chart should be kept and any sustained rise immediately reported. It is emphasized that this was the first sign in both the above patients.

If gas infection is suspected, vigorous treatment should be instituted:

(1) The wound should be widely opened and a swab taken for bacteriological examination.

(2) Blood transfusion should be commenced as soon as possible as these patients all have some degree of haemolysis.

(3) Penicillin should be given as above.

(4) Hyperbaric oxygen can be life-saving (Brummelkamp, Boerema \& Hoogendyk, 1963) though the salvage rate in these elderly arteriosclerotics will inevitably be disappointing. Until the patient can be placed in the oxygen pressurechamber, oxygen should be given by face-mask.

\section{Acknowledgments}

My thanks are due to Dr I. Howard, Medical Superintendent of the Alfred Hospital, Mr R. S. Lawson and Mr K. Bradley for permission to publish these case reports.

\section{References}

Brummelkamp, W.H., Boerema, I. \& Hoogendy , L. (1963) Treatment of clostridial infections with hyperbaric oxygen drenching. Lancet, i, 235.

Gye, R. Rountree, P.M. \& Lowenthal, J. (1961) Infection of surgical wounds with Clostridium welchii. Med.J. Aust. i, 761 .

Ham, J.M., Mackenzie, D.C. \& Lowenthal, J. (1964) The immediate results of lower limb amputation for atherosclerosis obliterans. Aust. N.Z. J. Surg. 34, 97.

Karasewick, E.G., Harper, E.M., Sharp, N.C.C., Shields, R.S., Smith, G. \& McDowall, D.G. (1964) Hyperbaric oxygen in clostridial infections. Clinical Application of Hyperbaric Oxygen (Ed. by I. Boerema). Proceedings of the First International Congress, 1963, pp. 36-40. Elsevier, Amsterdam.

NAGLER, F.P.O. (1945) Treatment of experimental gas gangrene due to Clostridium welchii with penicillin and antitoxin. Brit. J. exp. Path. 26, 57.

\title{
Primary Raynaud's disease associated with sclerodactyly and digital osteosclerosis
}

\author{
D. N. GoldING \\ M.A., M.D., M.R.C.P.I. \\ H. BAKER \\ M.B., Ch.B., M.R.C.P. \\ Princess Alexandra Hospital, Harlow, and \\ St John's Hospital for Diseases of the Skin, London
}

The Usual skeletal lesion associated with primary Raynaud's disease, or with Raynaud's phenomenon secondary to another disorder such as progressive systematic sclerosis, is digital osteoporosis affecting particularly the terminal phalanges of the hands. Rarely there may be progression to osteolysis of the terminal phalanges associated with wasting of the pulp and beaking of the nails, which in systemic sclerosis may be accompanied by ulceration of the tips of the fingers, indolent paronychia and sometimes soft tissue calcification.

Increased bone density (osteosclerosis) of the metacarpals and phalanges is rarely found in association with Raynaud's disease, and is not mentioned in the majority of relevant textbooks. The following case is of interest because of the existence of both osteosclerosis and sclerodactyly, apparently secondary to Raynaud's disease.

\section{Case report}

A 45-year-old housewife stated that ever since childhood she had been prone to attacks of numbness and pallor followed by blueness and then redness of the hands, precipitated by cold. Her feet were affected to a lesser degree. The episodes were more severe in winter, when she regularly suffered from chilblains, but they occurred throughout the year. During adolescence she had observed wasting of the ulnar three fingers of the left hand, which progressed for a while and then became stationary. Lately she had noticed that the left hand was habitually colder and bluer than its fellow. 